DOI: $10.20535 /$ kpisn.2021.1.217992

UDC 681.5 .013

\author{
Yu.I. Mariiash*, O.V. Stepanets \\ Igor Sikorsky Kyiv Polytechnic Institute, Kyiv, Ukraine \\ *corresponding author: mariahyuriy@gmail.com
}

\title{
MODEL PREDICTIVE CONTROL TOOLBOX DESIGN FOR NONSTATIONARY PROCESS
}

Background. Model predictive control (MPC) approach is the basic feedback scheme, combined with high adaptive properties, which determines its successful use in the practice of design and operation of control systems. These advantages allow managing multidimensional objects with a complex structure, including nonlinearity, optimizing processes in real time within the constraints on controlled and managed variables, taking into account uncertainties in the task of objects and perturbations.

Objective. The purpose of the paper is to design and analyse control system of carbon monoxide oxidation in the convector cavity based on MPC with linear-quadratic cost functional with constraint.

Methods. The design of MPC is based on mathematical model of an object (relatively simple). At the current step, the prediction of object dynamic response on some final period of time (prediction horizon) is carried out; control optimization is performed, the purpose of which is to approximate the control variables of the prediction model to the corresponding setpoint on the predict horizon. The found optimal control is applied and measurement of an actual state of object at the end of a step is carried out. The prediction horizon is shifted one step further, and this algorithm are repeated.

Results. The results of modeling the automatic control system show that the MPC approach provides maintenance of carbon dioxide content when changing oxygen consumption and overshoot caused by introduction bulk does not exceed $0.6 \%$ that meets the technological requirements of the process.

Conclusions. A fuse of the MPC and the quadratic functional given the constraints on the input signals is proposed. The problems of control degree of carbon oxidation in the convector cavity include non-stationarity, so the use of classical control methods is difficult. The MPC approach minimizes the cost function that characterizes the quality of the process. The predicted behaviour of a dynamic system will usually differ from its actual motion. The obtained quadratic functional is optimized to find the optimal control of degree of $\mathrm{CO}$ oxidation to $\mathrm{CO}_{2}$.

Keywords: model predictive control; linear-quadratic cost functional; state space model; control system.

\section{Introduction}

The idea of optimizing the predicted control action, which forms the basis of model predictive control (MPC) methods, has arisen within the framework of two independent approaches. The first one is known as Model Algorithmic Control (MAC) presented by Richalet et al. [1] proceedings and the second one is Dynamic Matrix Control (DMC) presented by Cutler and Ramaker [2] proceedings. The evolution of the MPC and the overview of its industrial applications are described in [3]. Although $90 \%$ of all controllers use PID-laws [4], MPC has quickly became famous, particularly in the chemical process industries due to simplicity of the algorithm and to the use of the impulse or step response model.

The general set of MPC strategy components consists of a process model, a performance index, constraints and an optimization method. Process models can be both linear and nonlinear or even a set of model combination [5-7] with input and/or output constraints as an explicit part of the models. P. Tatjewski, M. Ławryńczuk in [8] assume that such processes exist under influence of external disturbances and their models are not precise. A comprehensive comparison of disturbance state modelling approaches is described. A performance index, also known as the cost function, is designed in such way that makes possible to get a convex space of solution variations. It requires application of optimization algorithms. In some cases [9] it is not so difficult to relate the cost function to economic performance. The receding horizon - a quantity of computing steps of the future model states based on the present and past system conditions - is an additional adjustment parameter of a final control law.

Some researchers combine MPC with different control approaches like fuzzy-logic [10], artificial neural networks [11] or it can be used for optimal set points or tracking trajectories [12] for local control loops with familiar controllers. Hierarchical structures of MPC because of complexity of closed solutions are proposed in [13]. The tradeoff between the achieved performance and complexity of the implementation in an application for process control industry is investigated in [14]. 
Nowadays MPC is used not only for direct control or process optimization but also as supervisor for other control technologies. For example, Hewing et al. [15] use MPC to ensure safety of a data-driven control approach during a self-learning phase.

There are many ways how to design the MPC system depending on goals, chosen models, existing constraints, expected system behaviour and disturbances. So, the application of MPC to the particular technological system can give great opportunities but still it is an actual scientific and practical problem.

\section{Problem statement}

The aim of the study is design and analysis of MPC system with quadratic cost function, and with constraint and features of MPC applications.

To achieve this goal, it is necessary to solve the following tasks:

- explore the strategy of the MPC;

- analyse the features of quadratic cost function with constraint;

- perform design of the control system.

\section{MPC strategy}

In the control strategy with the principle of feedback of dynamic objects is used the basic idea of all the MPC approaches (Fig. 1):

1. A mathematical model of control object (relatively simple) is considered, which initial conditions are determined by its current state. At the current control action, the prediction of object dynamic response on some final period of time (prediction horizon) is carried out.

2. The control optimization is performed, the purpose of which is to approximate the control variables of the prediction model to the corresponding set-point on the prediction horizon.

3. Then the found optimal control is applied and measurement of an actual state of the control object at the end of a step is carried out.

4. The prediction horizon is shifted one step further, and points $1-3$ of this algorithm are repeated.

The main advantage of the MPC approach, which determines its successful use in the practice of design and operation of control systems, is the relative simplicity of the basic feedback scheme, combined with high adaptive properties. The latter allows managing multidimensional objects with a complex structure, including nonlinearity, optimizing processes in real time within the constraints on controlled and managed variables, taking into account process uncertainties and perturbations. In addition, it is possible to take into account changes in control quality criteria and sensor failures.

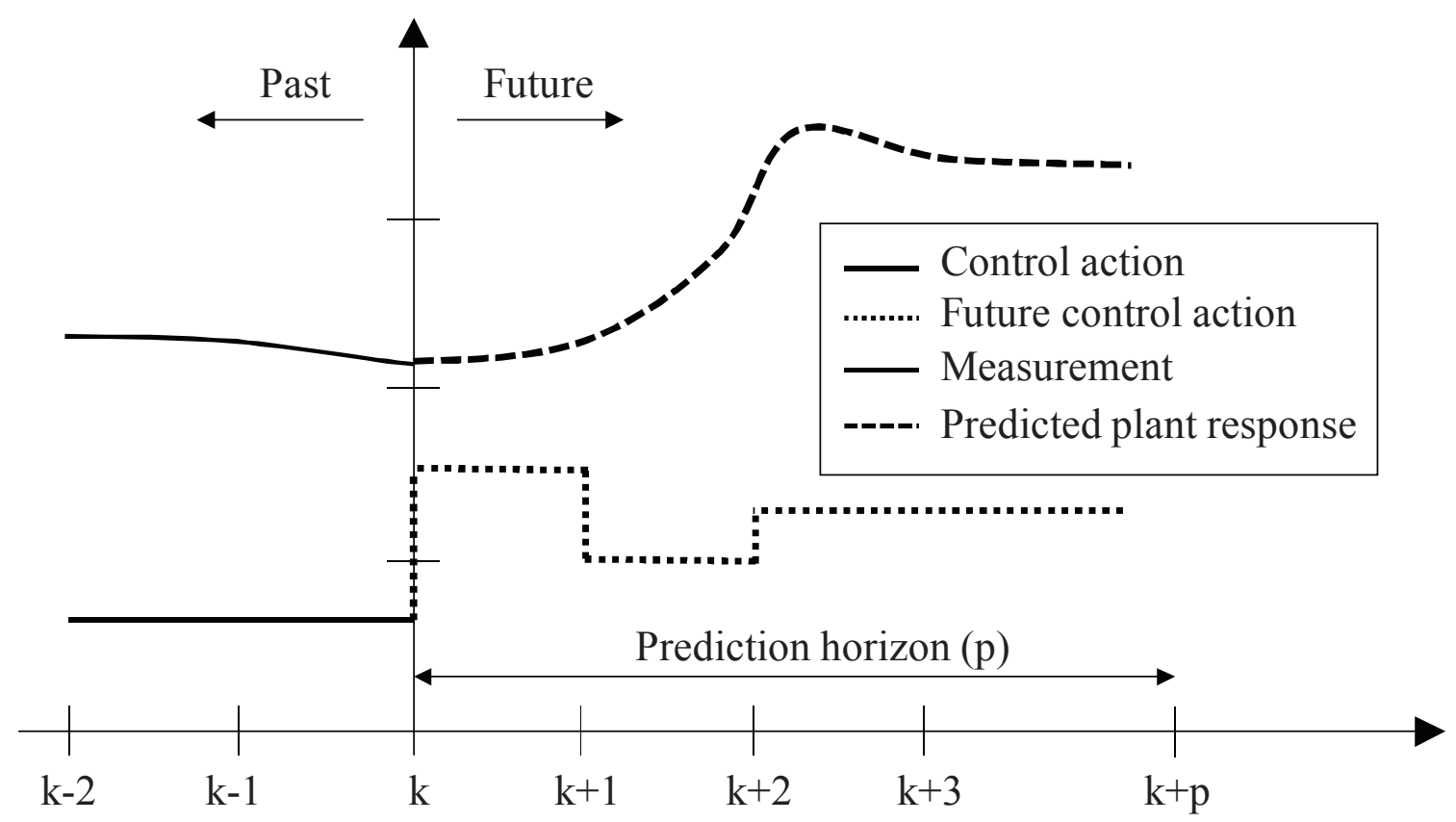

Fig. 1. MPC strategy 
MPC with quadratic cost function with constraints on input and output variables

The task of MPC is reduced to the usual proportional feedback controller on the state of an object, which is not fundamentally different from the LQ-optimal controllers. But the situation changes fundamentally, given the constraint on the control effect and the state of the control object, which significantly limits the set of controllers in the problem of LQ-optimization. Obtaining an accurate optimal solution for controls in real time is quite problematic, which significantly increases the validity of the MPC strategy. is used:

Here the equation of the predictive model (1)

$$
\begin{aligned}
& x_{i+1}=A x_{i}+B u_{i}, \\
& y_{i}=C x_{i}, \\
& i=k+j, j=0,1,2 \ldots,
\end{aligned}
$$

where $k$-step; $x_{i} \in E^{n}$ - state; $y_{i} \in E^{r}$ - measurement; $u_{i} \in E^{m}-$ control action;

The predictive model is close to the real object in terms of dynamic properties. Let the predictive model (1) at the current time $(j=0)$ be initialized by the state of the actual control object and the equality $u_{i}=\tilde{u}_{i}$ for $\forall i=k, k+1 \ldots, k+P$ is satisfied. The quality of optimal control is characterized by the linear-quadratic functional:

$$
\begin{gathered}
J_{k}=J_{k}(\bar{y}, \Delta \bar{u})= \\
\sum_{j=1}^{P}\left[\left(y_{k+j}-r_{k+j}\right)^{T} R_{k+j}\left(y_{k+j}-r_{k+j}\right)+\right. \\
\left.\Delta u_{k+j-1}^{T} Q_{k+j} \Delta u_{k+j-1}\right],
\end{gathered}
$$

where $R_{k+j}$ and $Q_{k+j}$ are positively defined symmetric matrices.

Here additional vectors are:

$$
\begin{gathered}
\bar{y}=\left(y_{k+1} y_{k+2} \ldots y_{k+P}\right)^{T} \in E^{r P}, \\
\bar{u}=\left(\Delta u_{k} \Delta u_{k+1} \ldots \Delta u_{k+P-1}\right)^{T} \in E^{m P} .
\end{gathered}
$$

The use of the functional (2) allows ensuring the astatism of a closed system. Consider the optimization problem:

$$
J_{k}=J_{k}(\bar{y}(\Delta \bar{u}), \Delta \bar{u})=J_{k}(\Delta \bar{u}) \rightarrow \min _{\frac{\Delta u}{\Delta E^{m P}}}
$$

regarding finding the sequence of vectors that minimizes the functional (2) without taking into account the constraints. In accordance with the approach adopted to ensure astatism, we will form additional predictive model:

$$
\begin{aligned}
& p_{i+1}=\bar{A} p_{i}+\bar{B} v_{i}, \\
& z_{i}=\bar{C} p_{i}, \\
& i=k+j, j=0,1,2 \ldots,
\end{aligned}
$$

where $p_{k}=\left(\frac{x_{k}-x_{k-1}}{C x_{k}}\right)$, with matrices $\bar{A}, \bar{B}, \bar{C}$ :

$$
\bar{A}=\left(\begin{array}{cc}
A & 0_{n \times r} \\
C A & E_{r \times r}
\end{array}\right), \bar{B}=\left(\begin{array}{c}
B \\
C B
\end{array}\right), \bar{C}=\left(\begin{array}{ll}
0_{r \times n} & E_{r \times r}
\end{array}\right) .
$$

The inputs for the model (4) are in the vector, $v_{i}=\Delta \bar{u}$, and the outputs are $z_{i}=y_{i}$. Given (4), the functional (3) can be represented in the equivalent form:

$$
\begin{gathered}
J_{k}=J_{k}(\bar{z}(\bar{v}), \bar{v})= \\
\sum_{j=1}^{P}\left[\left(z_{k+j}-r_{k+j}\right)^{T} R_{k+j}\left(z_{k+j}-r_{k+j}\right)+v_{k+j-1}^{T} Q_{k+j} v_{k+j-1}\right]= \\
(\bar{z}-\bar{r})^{T} R(\bar{z}-\bar{r})+\bar{v}^{T} Q \bar{v}
\end{gathered}
$$

where

$$
\begin{aligned}
& \bar{z}=\left(\begin{array}{llll}
z_{k+1} & \mathrm{z}_{k+2} & \ldots \mathrm{z}_{k+P}
\end{array}\right)^{T} \in E^{r P}, \\
& \bar{v}=\left(\begin{array}{llll}
v_{k} & v_{k+1} \ldots v_{k+P-1}
\end{array}\right)^{T} \in E^{m P} .
\end{aligned}
$$

Given $\bar{z}=L p_{k}+M \bar{v}$, the matrices $L, M$ are determined as follows:

$$
L=\left(\begin{array}{c}
\bar{C} \bar{A} \\
\bar{C} \bar{A}^{2} \\
\ldots \ldots . \\
\bar{C} \bar{A}^{P}
\end{array}\right)=\left(\begin{array}{cc}
C A & E_{r \times r} \\
C A^{2} & E_{r \times r} \\
\ldots \ldots & E_{r \times r} \\
C A^{P} & E_{r \times r}
\end{array}\right),
$$

$$
M=\left(\begin{array}{llll}
\bar{C} \bar{A} & 0 & \cdots & 0 \\
\bar{C} \bar{A} \bar{B} & \bar{C} \bar{B} & \cdots & 0 \\
\cdots & \cdots & \cdots & \\
\bar{C} \bar{A}^{P-1} \bar{B} & \bar{C} \bar{A}^{P-2} \bar{B} & \cdots & \bar{C} \bar{B}
\end{array}\right)=
$$

$$
\left(\begin{array}{llll}
C B & 0 & \cdots & 0 \\
C A B+C B & C B & \cdots & 0 \\
\cdots & \cdots & \cdots & \\
\sum_{i=0}^{P-1} C A^{i} B & \sum_{i=0}^{P-2} C A^{i} B & \cdots & C B
\end{array}\right) .
$$



follows:

The cost function (5) can be represented as

$$
J_{k}=J_{k}(\bar{v})=\bar{v}^{T} H \bar{v}+2 f^{T} \bar{v}+g,
$$

where $H=M^{T} R M+Q, \quad f=M^{T} R L p_{k}-M^{T} R \bar{r}$, $g=p_{k}^{T} L^{T} R L p_{k}+r^{T} R \bar{r}-2 p_{k}^{T} L^{T} R \bar{r}$.

And the following constraints are taken into account:

$$
\left\{\begin{array}{l}
u_{i}^{-} \leq u_{i} \leq u_{i}^{+}, \\
\Delta u_{i}^{-} \leq \Delta u_{i} \leq \Delta u_{i}^{+}, \\
y_{i}^{-} \leq y_{i} \leq y_{i}^{+},
\end{array}\right.
$$

where $u_{i}^{-}, u_{i}^{+}, \Delta u_{i}^{-}, \Delta u_{i}^{+}, y_{i}^{-}, y_{i}^{+}$are given vectors. duced:

Given (6) the following notation can be intro-

$$
\begin{aligned}
& \bar{y}_{\text {min }}=\left(\begin{array}{llll}
y_{k+1}^{-} & y_{k+2}^{-} & \ldots & y_{k+P}^{-}
\end{array}\right), \\
& \bar{u}_{\min }=\left(\begin{array}{llll}
u_{k}^{-} & u_{k+1}^{-} & \ldots & u_{k+P-1}^{-}
\end{array}\right) \text {, } \\
& \Delta \bar{u}_{\min }=\left(\Delta{u^{-}}_{k} \Delta{u^{-}}_{k+1} \ldots \Delta u_{k+P-1}^{-}\right) \text {, } \\
& \bar{y}_{\max }=\left(\begin{array}{llll}
y_{k+1}^{+} & y^{+}{ }_{k+2} & \ldots & y^{+}{ }_{k+P}
\end{array}\right), \\
& \bar{u}_{\max }=\left(\begin{array}{llll}
u^{+}{ }_{k} & u^{+}{ }_{k+1} & \ldots & u^{+}{ }_{k+P-1}
\end{array}\right), \\
& \Delta \bar{u}_{\max }=\left(\Delta{u^{+}}_{k} \Delta{u^{+}}_{k+1} \ldots \Delta{u^{+}}_{k+P-1}\right) \text {. }
\end{aligned}
$$

The control action $u_{k-1}$ is known. Then for the step $k$ it is fair $u_{\kappa}=u_{k-1}+\Delta u_{\kappa}$; from here

$$
\bar{u}=M_{0} u_{k-1}+M_{u} \Delta \bar{u},
$$

$M_{0}=\left(\begin{array}{c}E_{m \times m} \\ E_{m \times m} \\ \ldots \ldots \\ E_{m \times m}\end{array}\right), M_{u}=\left(\begin{array}{cccc}E_{m \times m} & 0 & \ldots . . & 0 \\ E_{m \times m} & E_{m \times m} & \ldots . . & 0 \\ \ldots \ldots & \ldots . . & \ldots . . & 0 \\ E_{m \times m} & E_{m \times m} & \ldots . . & E_{m \times m}\end{array}\right)$.

Given $\bar{z}=L p_{k}+M \bar{v}$ and (7), constraints (6) can be represented as the system of linear inequalities:

$$
A_{v} \bar{v} \leq A_{i m}+A_{p} p_{k}+A_{u} p_{k-1} .
$$

Now instead of problem (5) it is possible to substitute the problem with constrains

$$
J_{k}=J_{k}(\bar{v})=\bar{v}^{T} H \bar{v}+2 f^{T} \bar{v}+g \rightarrow \min _{v \in V \in E^{m P}}
$$

on the admissible set of controls as follows:

$$
V=\left\{\bar{v} \in E^{m P}: A_{v} \bar{v} \leq A_{i m}+A_{p} p_{k}+A_{u} p_{k-1}\right\} .
$$

The result of solving this problem will determine optimal sequence of vectors $v_{i}=\Delta u_{i}, i=k, k+1, \ldots, k+P-1$. The formula $u_{k}=u_{k-1}+\Delta u_{k}$ determines the control action at the current step and according to the MPC strategy the process of determining the optimal trajectory is repeated.

It should be noted that if the matrix $H$ in the functional (8) is positive, then minimization of the functional in the presence of constraints is reduced to the standard problem of numerical analysis convex quadratic programming.

\section{MPC application}

The basic oxygen furnace is an appropriate object for automatic MPC system. The degree of carbon oxidation to carbon dioxide in the convector cavity was taken for the study of MPC application. The obtained study results can be extrapolated to the objects with similar dynamics. The problems of control degree of $\mathrm{CO}$ oxidation in the convector cavity include non-stationarity of the decarburization rate, complexity of measurements, and disturbances: changes in the flow rate of oxygen, introduction of bulk, etc. The control object in the channel "the lance distance to the level of a quiet bath - the degree of $\mathrm{CO}$ oxidation to $\mathrm{CO}_{2}$ " is described by the differential equation [15]:

$$
T_{v_{c}} T_{\gamma_{\mathrm{CO}_{2}}} \frac{d^{2} \gamma_{\mathrm{CO}_{2}}}{d t^{2}}+\left(T_{v_{c}}+T_{\gamma_{\mathrm{CO}_{2}}}\right) \frac{d \gamma_{\mathrm{CO}_{2}}}{d t}+\gamma_{\mathrm{CO}_{2}}=k_{\gamma_{\mathrm{CO}_{2}}}^{H} H
$$

where $\gamma_{\mathrm{CO}_{2}}$ is the degree of carbon oxidation to carbon dioxide, $\% ; H$ is the distance of the lance to the level of a quiet bath, $\mathrm{m} ; T_{v_{c}}, T_{\gamma_{\mathrm{CO}_{2}}}[s]$ is time constant; $k_{\gamma_{\mathrm{CO}_{2}}}^{H}$ is the transmission coefficient through the channel distance of lance to the level of a quiet bath - the degree of carbon oxidation, $\frac{\%}{\mathrm{~m}}$.

The process of changing the rate of decarburization is non-stationary model (9) also depends on the melting period:

$$
\begin{gathered}
T_{\gamma_{\mathrm{CO}_{2}}}=2,15 \mathrm{~s} ; \\
T_{v_{c}}, \mathrm{~s}=
\end{gathered}
$$

$1,143+4,446 \cdot \tau-0,484 \cdot \tau^{2}, 1$ period

$\{11,267,2$ period

$11,267-4,446 \cdot(\tau-16)+0,484 \cdot(\tau-16)^{2}, 3$ period 


$$
k_{\gamma_{\mathrm{CO}_{2}}}^{H}, \frac{\%}{\mathrm{~m}}=
$$

$\left(4,75+2,43 \cdot \tau-0,26 \cdot \tau^{2}+0,013 \cdot \tau^{3}, 1\right.$ period, $11,87,2$ period

$11,87-3,63 \cdot(\tau-16)+0,4 \cdot(\tau-16)^{2}+$

$0,019 \cdot(\tau-16)^{3}, 3$ period,

where $\tau-$ purging time, min.

The equation of the predictive model is used by MPC (10):

$$
\begin{aligned}
& {\left[\begin{array}{c}
x_{1}^{\prime}(t) \\
x_{2}^{\prime}(t)
\end{array}\right]=\left[\begin{array}{cc}
0, & 1 \\
-\frac{1}{T_{v_{c}}(t) T_{\gamma_{\mathrm{CO}_{2}}}}, & -\frac{T_{v_{c}}(t)+T_{\gamma_{\mathrm{CO}_{2}}}}{T_{v_{c}}(t) T_{\gamma_{\mathrm{CO}_{2}}}}
\end{array}\right]\left[\begin{array}{l}
x_{1}(t) \\
x_{2}(t)
\end{array}\right]+} \\
& {\left[\begin{array}{c}
0 \\
\frac{1}{T_{v_{c}}(t) T_{\gamma_{\mathrm{CO}_{2}}}}
\end{array}\right] H(t)} \\
& \gamma_{\mathrm{CO}_{2}}(t)=k_{\gamma_{\mathrm{CO}_{2}}}^{H}(t) x_{1}(t)
\end{aligned}
$$
account:

Here the following constraints are taken into
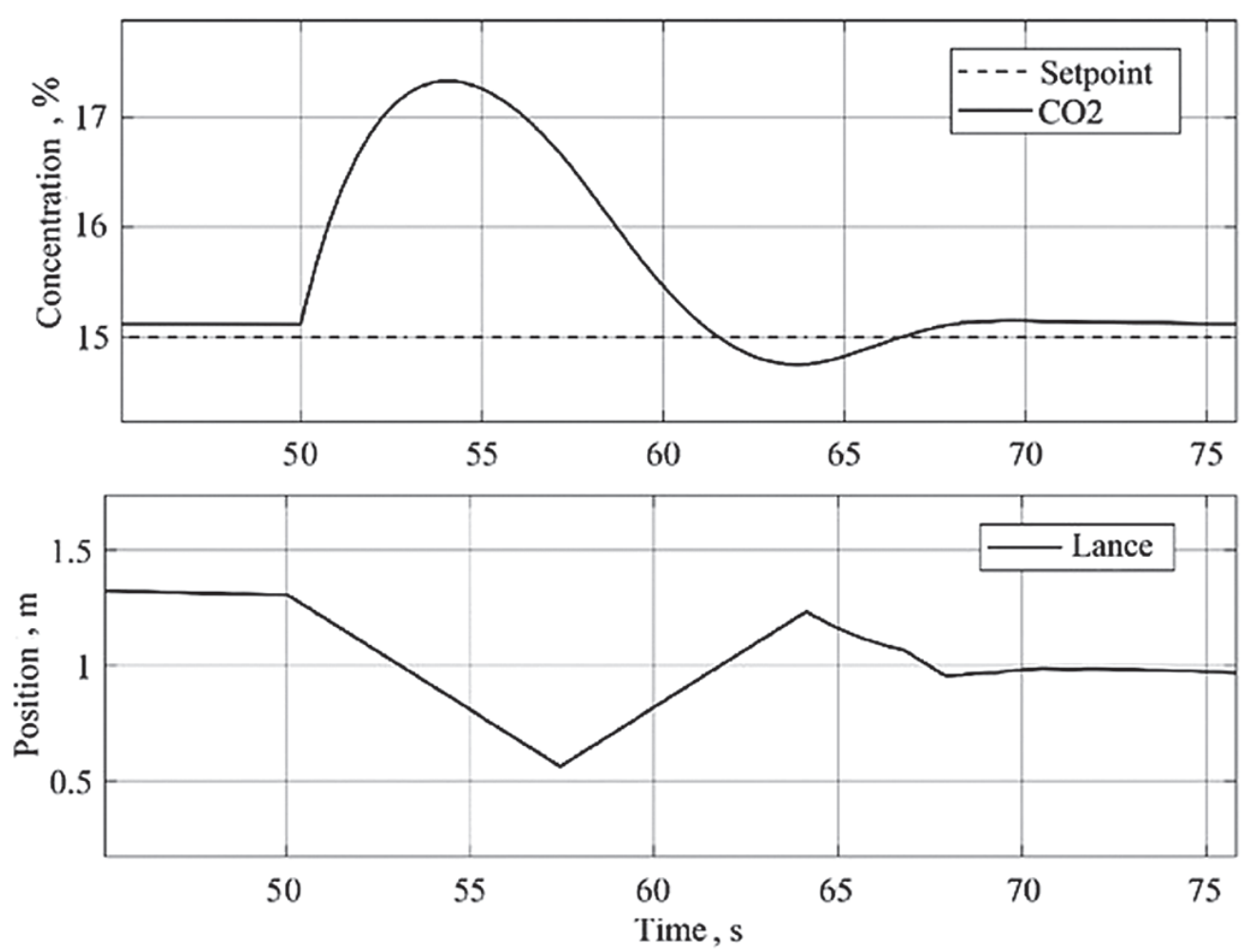

Fig. 2. The process in the control system of purging through the channel change in the lance distance $-\mathrm{CO}_{2}$ degree in the flue gases

$$
\left\{\begin{array}{l}
0.5 \leq H \leq 2.0 \\
-0.01 \leq \Delta H \leq 0.01
\end{array}\right.
$$

The purpose of control is achievement of a given degree of carbon oxidation to carbon dioxide within acceptable constraints, so the energy savings on the movement of the lance is not taken into account in the cost function (11). The quality of control is characterized by the linear-quadratic functional:

$$
\begin{gathered}
J_{k}=J_{k}\left(\gamma_{\mathrm{CO}_{2}}(\Delta H)\right)= \\
\sum_{j=1}^{P}\left[\left(\left(\gamma_{\mathrm{CO}_{2}}\right)_{k+j}-\left(\gamma_{\mathrm{CO}_{2}}\right)_{k+j}\right)^{2}\right] .
\end{gathered}
$$

For the control system of $\mathrm{CO}_{2}$ concentration, the main task is the problem of stabilization (Fig. 2) in the event of disturbances availability: changes in the flow rate of oxygen, change in the rate of decarburization, introduction of bulk etc. The transitions through the disturbances for perturbation-output channel are shown in Fig. 2.

The simulation of process during purging for a 160-ton converter is shown in Fig. 3. Oxygen flow is changing sinusoidally; the disturbances (introduction of bulk) are applied at $220 \mathrm{~s}$. 

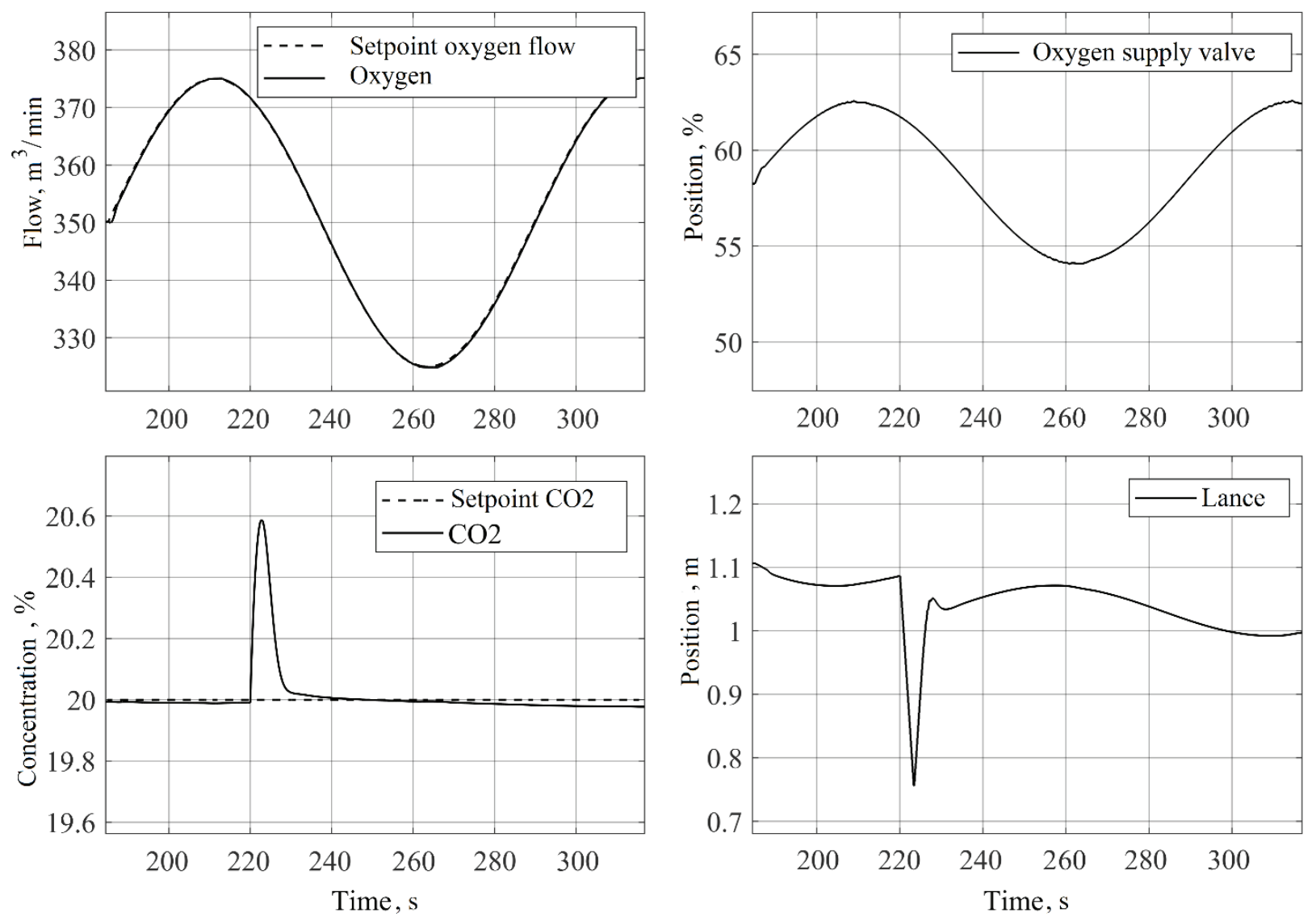

Fig. 3. The processes of the automatic control system for oxygen converter melting

The processes in the automatic control system show that the MPC approach provides maintenance of carbon dioxide content when changing oxygen consumption. The overshoot caused by introduction of bulk at 220s (Fig. 3) does not exceed $0.6 \%$ that meets the technological requirements of the process.

\section{Conclusions}

A fuse of the MPC and the quadratic functional given the constraints on the input signals is proposed. The problems of $\mathrm{CO}_{2}$ concentration control in the convector cavity include non-stationarity, so the use of classical control methods is difficult. The MPC approach minimizes the cost function that characterizes the quality of the process. The predicted behaviour of dynamic system will usually differ from its actual motion. The obtained quadratic functional is optimized to find the optimal control of the carbon oxidation degree. The approach takes into account the constraints imposed on the control input and output. To operate the control system in real time, it is necessary that the solution to the optimization problem is carried out quickly enough. The degree of $\mathrm{CO}$ oxidation to $\mathrm{CO}_{2}$ was simulated. The simulation results show that the control system satisfies the necessary requirements for the system. This control approach can be extended to other heat power facilities with similar dynamics. The cost function can vary depending on the goal, including the exergy analysis of energy consumption for value production.

\section{Acknowledgement}

This work was supported by Ministry of Education and Science of Ukraine, project number $0120 \mathrm{U} 102168$. 


\section{References}

[1] J. Richalet et al., "Model predictive heuristic control," Automatica, vol. 14, no. 15, pp. 413-428, 1978. doi: 10.1016/0005-1098(78)90001-8

[2] C.R. Cutler and B.L. Ramaker, "Dynamic matrix control - A computer control algorithm," in Proc. Joint Automatic Control Conf., Houston, TX, 1980.

[3] S.J. Qin and T.A. Badgwell, "A survey of industrial model predictive control technology," Control Eng. Pract., vol. 11, no. 7, pp. 733-764, 2003. doi: 10.1016/S0967-0661(02)00186-7

[4] O. Stepanets and Yu. Mariiash, "Analysis of influence of technical features of a pidcontroller implementation on the dynamics of automated control system," Eastern-Europ. J. Enterpr. Technol., vol. 3, no. 2 (93), pp. 60-69, 2018. doi: $10.15587 / 1729-4061.2018 .132229$

[5] S. Dubljevic and J.P. Humaloja, "Model predictive control for regular linear systems," Automatica, vol. 119, p. $109066,2020$. doi: $10.1016 / j$.automatica.2020.109066

[6] F. D. Palma and L. Magni, "A multi-model structure for model predictive control," Ann. Rev. Control, vol. 28, no. 1, pp. 47-52, 2004. doi: 10.1016/j.arcontrol.2004.01.004

[7] M.M. Morato et al., "Model predictive control design for linear parameter varying systems: A survey," Ann. Rev. Control, vol. 49, pp. 64-80, 2020. doi: 10.1016/j.arcontrol.2020.04.016

[8] P. Tatjewski and M. Ławryńczuk, "Algorithms with state estimation in linear and nonlinear model predictive control," Comput. \& Chem. Eng., vol. 143, p. 107065, 2020. doi: 10.1016/j.compchemeng.2020.107065

[9] Y. Iino and T. Shigemasa, "Model predictive control with multi-objective cost function considering stabilization and linear cost optimization," IFAC Proc. Vol., vol. 30, no. 9, pp. 547-552, 1997. doi: 10.1016/S1474-6670(17)43206-X

[10] L. Böhler et al., "Fuzzy model predictive control for small-scale biomass combustion furnaces," Appl. Energy, vol. 276, p. 115339, 2020. doi: 10.1016/j.apenergy.2020.115339

[11] Y. Shin et al., "Development of model predictive control system using an artificial neural network: A case study with a distillation column,” J. Cleaner Prod., vol. 277, p. 124124, 2020. doi: 10.1016/j.jclepro.2020.124124

[12] L. Keviczky and Cs. Bányász, "Optimal structure for model predictive control," IFAC Proc. Vol., vol. 37, no. 12, pp. 621-626, 2004. doi: 10.1016/S1474-6670(17)31538-0

[13] M. Chen et al., "Cooperative distributed model predictive control based on topological hierarchy decomposition," Control Eng. Pract., vol. 103, p. 104578, 2020. doi: 10.1016/j.conengprac.2020.104578

[14] A. Maxim et al., "An industrially relevant formulation of a distributed model predictive control algorithm based on minimal process information,” J. Process Control, vol. 68, pp. 240-253, 2018. doi: 10.1016/j.jprocont.2018.06.004

[15] L. Hewing et al., "Learning-based model predictive control: Toward safe learning in control," Annual Rev. Control, Robotics, Autonom. Syst., vol. 3, no. 1, pp. 269-296, 2020. doi: 10.1146/annurev-control-090419-075625

[16] O. Stepanets and Yu. Mariiash, "Model predictive control application in the energy saving technology of basic oxygen furnace," Informatyka, Automatyka, Pomiary w Gospodarce i Ochronie Środowiska, vol. 10, no. 2, pp. 70-74, 2020. doi: 10.35784/iapgos.931

\section{Ю.І. Маріяш, О.В. Степанець}

\section{РОЗРОБЛЕННЯ МОДЕЛЬНО-ПРОГНОЗНОГО РЕГУЛЯТОРА ДЛЯ НЕСТАЦІОНАРНОГО ТЕХНОЛОГІЧНОГО ПРОЦЕСУ}

Проблематика. Модельно-прогнозне керування (МПК) використовує базову схему зворотного зв'язку, поєднану зі значними адаптивними властивостями, що визначає ії успішне застосування в проєктуванні та експлуатації систем управління. Ці переваги дають змогу керувати багатовимірними об'єктами зі складною структурою, що можуть містити нелінійності, оптимізувати цільову функцію в режимі реального часу в рамках обмежень на керовані та керівні змінні, враховувати невизначеності в описі об'єктів і збурень.

Мета дослідження. Розробити та проаналізувати систему керування окисленням монооксиду вуглецю в порожнині конвектора на базі МПК із лінійно-квадратичним фрункціоналом за наявності обмежень.

Методика реалізації. Розробка МПК базується на математичній прогнозній моделі об'єкта (повинна бути відносно простою). На поточному кроці прогнозують поведінку об'єкта на певний кінцевий проміжок часу (горизонт прогнозування); оптимізують критерій задля наближення відповіді прогнозної моделі до відповідного завдання на горизонті прогнозування. Далі застосовують перше значення знайденого керувального впливу та вимірюють фактичний стан об'єкта наприкінці кроку. Горизонт прогнозування зміщують на крок уперед, і цей алгоритм повторюють.

Результати дослідження. Результати моделювання автоматичної системи керування показують, що МпК-підхід забезпечує підтримання вмісту вуглекислого газу за зміни споживання кисню, а також перерегулювання, спричинене введенням сипучих компонентів, яке не перевищує 0,6 \% (це відповідає технологічним вимогам процесу).

Висновки. Запропоновано синтез МПК із квадратичним функціоналом з урахуванням обмежень на вхідні сигнали. Проблеми контролю ступеня окислення вуглецю в порожнині конвектора містять нестаціонарність, тому використання класичних методів управління ускладнене. Підхід МПК мінімізує цільову функцію, що характеризує якість процесу. Прогнозована поведінка 
об’єкта керування зазвичай відрізнятиметься від його фрактичного руху. Оптимальне керування ступенем згоряння СО до СО 2 знаходять оптимізацією отриманого лінійно-квадратичного функціонала.

Ключові слова: модельно-прогнозне керування; лінійно-квадратичний функціонал; модель в просторі станів; система керування.

\section{Ю.И. Марияш, А.В. Степанец}

\section{РАЗРАБОТКА МОДЕЛЬНО-ПРОГНОЗИРУЮЩЕГО РЕГУЛЯТОРА ДЛЯ НЕСТАЦИОНАРНОГО ТЕХНОЛОГИЧЕСКОГО} ПРОЦЕССА

Проблематика. Модельно-прогнозирующее управление (МПУ) использует базовую схему обратной связи, объединенную со значительными адаптивными свойствами, что определяет ее успешное использование в проектировании и эксплуатации систем управления. Эти преимущества позволяют управлять многомерными объектами со сложной структурой, которые могут включать нелинейности, оптимизировать целевую функцию в режиме реального времени в рамках ограничений на управляемые и управляющие переменные, учитывать неопределенности в описании объектов и возмущений.

Цель исследования. Разработать и проанализировать систему управления окислением монооксида углерода в полости конвектора на базе МПК с линейно-квадратичным функционалом при наличии ограничений.

Методика реализации. Разработка МПУ базируется на математической прогнозирующей модели объекта (должна быть относительно простой). На текущем шаге прогнозируют поведение объекта на определенный конечный промежуток времени (горизонт прогнозирования); оптимизируют критерий с целью приближения отклика прогнозирующей модели к соответствующему заданию на горизонте прогнозирования. Далее применяют первое значение найденного управляющего воздействия и измеряют фактическое состояние объекта в конце шага. Горизонт прогнозирования смещают на шаг вперед, и данный алгоритм повторяют.

Результаты исследования. Результаты моделирования автоматической системы управления показывают, что МПУ-подход обеспечивает поддержание содержания углекислого газа при изменении потребления кислорода, а также перерегулирование, вызванное введением сыпучих компонентов, не превышающее 0,6 \% (это соответствует технологическим требованиям процесса).

Выводы. Предложен синтез МПУ с квадратичным функционалом при учете ограничений на входные сигналы. Проблемы контроля степени окисления углерода в полости конвектора включают нестационарность, поэтому использование классических методов управления затруднено. Подход МПУ минимизирует целевую функцию, которая характеризует качество процесса. Прогнозируемое поведение объекта управления обычно будет отличаться от его фактического движения. Оптимальное управление степени сгорания СО до СО находится путем оптимизации полученного линейно-квадратичного функционала.

Ключевые слова: модельно-прогнозирующее управление; линейно-квадратичный функционал; модель в пространстве состояний; система управления.

Рекомендована Радою теплоенергетичного факультету КПІ ім. Ігоря Сікорського
Надійшла до редакції 05 грудня 2020 року

Прийнята до публікації 29 березня 2021 року 